\title{
THE ANNUAL MEETING OF THE SOCIETY
}

The fiftieth Annual Meeting of the American Mathematical Society was held at the Museum of Science and Industry, Chicago, Illinois, Friday and Saturday, November 26 and 27, 1943, in conjunction with meetings of the Mathematical Association of America. Over two hundred persons registered including the following one hundred sixtyfive members of the Society:

R. P. Agnew, A. A. Albert, C. B. Allendoerfer, B. H. Arnold, Max Astrachan, W. L. Ayres, R. W. Babcock, Reinhold Baer, R. M. Ballard, Harry Bateman, J. C. Bell, S. F. Bibb, B. H. Bissinger, L. M. Blumenthal, J. L. Brenner, R. W. Brink, J. O. Brown, R. H. Bruck, E. L. Buell, H. E. Burns, Herbert Busemann, Albert Cahn, W. D. Cairns, W. B. Carver, W. B. Caton, W. F. Cheney, E. W. Chittenden, R. V. Churchill, A. B. Coble, L. W. Cohen, N. B. Conkwright, A. H. Copeland, J. J. Corliss, D. R. Curtiss, M. M. Day, John DeCicco, J. J. Dennis, Jesse Douglas, Arnold Dresden, D. M. Dribin, Samuel Eilenberg, Wade Ellis, Paul Erdös, H. J. Ettlinger, H. P. Evans, H. S. Everett, G. M. Ewing, J. V. Finch, N. J. Fine, Edward Fleisher, L. R. Ford, R. H. Fox, J. S. Frame, Morris Friedman, T. C. Fry, J. H. Giese, J. W. Givens, Michael Golomb, Cornelius Gouwens, L. M. Graves, V. G. Grove, D. W. Hall, P. R. Halmos, R. W. Hamming, W. L. Hart, C. T. Hazard, M. H. Heins, E. D. Hellinger, Edward Helly, Fritz Herzog, E. H. C. Hildebrandt, T. H. Hildebrandt, D. L. Holl, A. S. Householder, H. K. Hughes, Ralph Hull, M. G. Humphreys, Mildred Hunt, H. D. Huskey, M. H. Ingraham, B. W. Jones, William Karush, Robert Kates, D. E. Kearney, I. F. Keeler, Fred Kiokemeister, J. R. Kline, L. A. Knowler, W. C. Krathwohl, E. P. Lane, R. E. Langer, E. H. Larguier, C. G. Latimer, D. H. Leavens, R. H. Lence, A. L. Lewis, M. I. Logsdon, A. T. Lonseth, Eugene Lukacs, Janet MacDonald, C. C. MacDuffee, Morris Marden, A. V. Martin, W. T. Martin, Karl Menger, E. J. Mickle, H. J. Miser, W. L. Mitchell, C. W. Moran, Marston Morse, E. J. Moulton, S. B. Myers, A. L. Nelson, C. V. Newsom, K. L. Nielsen, Ivan Niven, E. A. Nordhaus, E. P. Northrop, C. D. Olds, Isaac Opatowski, W. V. Parker, B. C. Patterson, Tibor Rad6, G. Y. Rainich, R. B. Rasmusen, W. T. Reid, Haim Reingold, W. H. Roever, R. G. Sanger, A. T. Schafer, R. D. Schafer, O. F. G. Schilling, G. E. Schweigert, M. E. Shanks, H. A. Simmons, G. W. Smith, I. S. Sokolnikoff, C. F. Stephens, N. E. Steenrod, A. H. Stone, D. M. Stone, M. H. Stone, E. B. Stouffer, R. L. Swain, J. L. Synge, R. M. Thrall, W. J. Trjitzinsky, S. M. Ulam, H. S. Wall, S. E. Warschawski, Warren Weaver, K. W. Wegner, J. V. Wehausen, C. P. Wells, E. T. Welmers, M. E. Wescott, M. D. Wetzel, G. W. Whitehead, G. T. Whyburn, L. R. Wilcox, R. L. Wilder, K. P. Williams, R. S. Wolfe, J. W. T. Youngs, Daniel Zelinsky.

Sessions for the reading of contributed papers were held Friday at 9:30 A.M. and 2:00 P.M. and Saturday at 10:45 A.M. and 3:15 P.M. The presiding officers for these sessions were Professors L. R. Ford, R. E. Langer, R. L. Wilder, and Dean M. H. Ingraham.

Friday morning following the session for contributed papers, Professor Reinhold Baer of the University of Illinois delivered an address 
entitled The higher sommutator subgroups. Professor A. A. Albert presided for this address.

Friday evening Professor Harry Bateman delivered the seventeenth Josiah Willard Gibbs Lecture on The control of elastic fluids. President M. H. Stone presided.

The annual business meeting and election of officers was held on Saturday morning, President Stone presiding. At the close of the business session President Stone announced the sixth award of the Bôcher Memorial Prize to Professor Jesse Douglas of Brooklyn College for his memoirs:

(a) Green's function and the problem of Plateau, American Journal of Mathematics, volume 61 (1939) pp. 545-589.

The most general form of the problem of Plateau, American Journal of Mathematics, volume 61 (1939) pp. 590-609.

(b) Solution of the inverse problem of the calculus of variations, Transactions of the American Mathematical Society, volume 50 (1941) pp. 71-128.

Professor Douglas then gave a résumé of his prize-winning papers.

Saturday afternoon with President Stone presiding, Professor Marston Morse of the Institute for Advanced Study delivered the Retiring Presidential Address entitled New settings for topology in analysis.

Sessions of the Mathematical Association of America were held on Saturday evening and Sunday morning. At the business meeting of the Association on Sunday morning Professors C. V. Newsom and G. M. Ewing presented a resolution of appreciation to the officials of the Museum of Science and Industry and the local committee on arrangements on behalf of the two mathematical organizations.

At the meeting of the Board of Trustees at 6:00 P.M., November 26, 1943 , in the Hotel Windermere East, there was no quorum present and the Board adjourned to January 8, 1944. The Council met at 9:30 P.M. on November 26, 1943, in the Hotel Windermere East.

The Secretary announced the election of the following twelve persons to membership in the Society:

Mr. R. H. Bing, University of Texas;

Mr. Patrik Butler, University of Texas;

Dr. Shiing-shen Chern, Institute for Advanced Study;

Professor Russell Dunholter, College of Engineering and Commerce, University of Cincinnati;

Professor William Henry Fagerstrom, College of the City of New York;

Professor Alois Joseph Lorenz, St. Michael's College, Winooski Park, Vt.;

Dr. Earl John Mickle, Ohio State University; 
Mr. Calvin Northrup Mooers, Naval Ordinance Laboratory, Washington, D. C.;

Dr. Chaim Leib Pekeris, Massachusetts Institute of Technology;

Professor Louis Wright Roberts, Howard University;

Dr. John Daniel Rommel, Jr., U.S.N.R., San Diego, Calif.;

Dr. Gail Sellers Young, Jr., Purdue University.

It was reported that the following had been elected as nominees on the institutional memberships of the institutions indicated:

Columbia University: Messrs. Robert Nathan Ascher, Edmund Churchill, and Huseyin Demir, Miss Aida Kalish, Messrs. Howard Levene, Robert King Ritt, and Cengiz Uluçay.

Michigan State College: Mr. Lawrence Duncan Childs.

University of Minnesota: Mr. Henry Damon Colson.

Ohio State University: Dr. Leslie Haynes Miller, Mr. Herbert Charles Parrish.

University of Pennsylvania: Mr. Richard Crowley Campbell.

The following appointments by Acting President C. C. MacDuffee were reported: as an auditor of the Society's accounts for 1943, Professor T. F. Cope; as tellers for the election at the 1943 Annual Meeting, Professors W. C. Krathwohl and E. R. Lorch, Dr. W. C. Strodt; as an editorial committee for Mathematical Surveys, to serve until December 31, 1944, Professors F. D. Murnaghan (Chairman), A. A. Albert, and T. H. Hildebrandt; as a Committee on the Award of the Cole Prize in Algebra, to be awarded at the 1944 Annual Meeting for papers published during the period 1939-1943, Professors E. T. Bell (Chairman), A. A. Albert, and N. H. McCoy; as a member of the Committee on Places of Meetings, for a period of three years beginning 1944, Professor C. R. Adams (committee now consists of Professors W. B. Carver, Chairman, C. R. Adams, and E. W. Chittenden); as new members of the Committees to Select Hour Speakers: for Annual and Summer Meetings, Professor J. D. Tamarkin (committee now consists of Professors J. R. Kline, Chairman, J. D. Tamarkin, and R. L. Wilder); for Eastern Sectional Meetings, Professor E. J. McShane (committee now consists of Professors T. R. Hollcroft, Chairman, E. J. McShane, and Saunders MacLane); for Western Sectional Meetings, Professor A. A. Albert (committee now consists of Professors W. L. Ayres, Chairman, A. A. Albert, and R. E. Langer); for Far Western Sectional Meetings, Professor Harry Bateman (committee now consists of Professors A. D. Michal, Chairman, Harry Bateman, and W. M. Whyburn).

Times and places of meetings during 1944 were set as follows: April 29 in Berkeley, California; April 28-29 in Chicago, Illinois; April 2829 in New York City.

Certain invitations to give hour addresses were announced: Pro- 
fessor E. L. Post for the February, 1944, meeting in New York City; Professors André Weil and E. R. Lorch for the April, 1944, meeting in New York City; Professor C. C. MacDuffee for the 1944 Summer Meeting.

The Secretary reported the resignations of Professors Saunders MacLane and G. B. Price from the Committee on Publicity (committee now consists of Professors R. M. Foster, Chairman, J. B. Rosser, and Dr. J. M. Thompson).

The Secretary reported that Professor Tibor Radó had accepted the invitation of the Council to deliver a set of Colloquium Lectures in 1945 and that the title of the Lectures will be Length and area.

The Council voted to invite Professor John von Neumann to deliver the eighteenth Josiah Willard Gibbs Lecture at the 1944 Annual Meeting.

The Secretary reported that the ordinary membership in the Society is now 2594, including 208 nominees of institutional members and 67 life members. There are also 87 institutional members. The total attendance at all meetings in 1943 was 1,028 ; the number of papers read was 278 ; there were 12 hour addresses, 6 symposium addresses, 3 Colloquium Lectures, 1 Gibbs Lecture, and a Retiring Presidential Address; the number of members attending at least one meeting was 619. The Secretary also reported the completion of the biennial membership campaign held during November when approximately 3,600 college teachers of mathematics, including 560 members of the Mathematical Association of America, were invited to membership in the Society.

At the annual election which closed on November 27, and at which 486 votes were cast, the following officers were elected:

Vice Presidents, Professors Einar Hille and G. T. Whyburn.

Associate Secretaries, Professors W. L. Ayres, A. D. Michal, and G. B. Price.

Member of the Editorial Committee of the Bulletin, Professor R. E. Langer.

Member of the Editorial Committee of the Transactions, Professor E. J. McShane.

Member of the Editorial Committee of the Colloquium Publications, Professor G. T. Whyburn.

Member of the Editorial Committee of Mathematical Reviews, Professor J. D. Tamarkin.

Member of the Editorial Committee of the American Journal of Mathematics, Professor Hassler Whitney.

Members-at-large of the Council, Professors Harry Bateman, Garrett 
Birkhoff, M. R. Hestenes, Harold Hotelling, Nathan Jacobson, R. D. James.

Professor J. W. T. Youngs of Purdue University was appointed Acting Associate Secretary to serve during the time that Associate Secretary G. B. Price is engaged in work for the government.

The Council adopted the following resolution concerning the work of Associate Secretary M. H. Ingraham in connection with the financial affairs of the Society:

With the retirement of Dean M. H. Ingraham from an Associate Secretaryship in the American Mathematical Society, the Council wishes to place on record an expression of its profound appreciation of his services rendered to the Society and to the cause of mathematics.

In the early nineteen thirties with at best a static income and with a rapidly expanding program of research publications, the responsible officers of the Society faced a problem of unusual difficulty. Various temporary expedients had been tried but the fact remained that either new funds of considerable magnitude must be tapped or the size of the journals drastically cut. Secretary Ingraham was at that time in large part responsible for putting into successful practice the scheme of individual contributing memberships by which members made voluntary increases in dues. But it soon became apparent that these extra funds were not sufficient to meet the situation. With the argument that the mathematicians had themselves made a real contribution to the balancing of the budget, it seemed possible to seek the financial backing of the universities. Professor Ingraham, one of the prime movers in this fruitful idea, was selected to interview university authorities. The Rockefeller Foundation, which over a period of years had been generous to the Society, was willing to pay the expenses of an extended trip among the mathematical centers.

Secretary Ingraham was remarkably successful not only in enlisting the support of the universities but also in leaving behind a friendlier and more understanding attitude toward research in mathematics. In each of the intervening years he kept in touch with the institutions which subscribed and, as a result, a sum of seventy-five hundred dollars has flowed annually into the treasury, thus enabling the publication program to be kept at a high level. And in a variety of other ways the Society has benefited from his leadership.

Perhaps no member of the Society is more widely known among his colleagues or has a larger circle of friends. The Council desires to extend hearty thanks on behalf of the Society and to wish him every success in his new duties at the University of Wisconsin.

Since the 1943 Annual Meeting was held before the close of the Society's fiscal year, it was impossible to present a full report of the Treasurer. (Excerpts from the final report of the Treasurer however appear on pages 29-32 of this Bulletin.) For the information of the Council a general statement on the current finances of the Society was presented. It was reported: (1) that total receipts for the fiscal year would exceed estimates and that the net excess of receipts over disbursements would probably be about $\$ 5,000$; (2) that income from individual and from institutional memberships would be at least as 
great as in 1942 ; (3) that the income from the sale of the Transactions would exceed estimates by nearly $\$ 1,000$, principally because of an unusual demand for back volumes; (4) that during 1943 the Society had received a full year's income, amounting to almost $\$ 4,000$, from the estate of Robert Henderson, a grant of $\$ 2,500$ from the Rockefeller Foundation for the use of the War Policy Committee, and the final payment on the principal of the Reilly Estate (the total receipts from the Reilly Estate amount to $\$ 23,651.47$ and have been added to the pooled investments of the Society).

The Librarian reported the following additions to the library: 41 books, 81 bound volumes of periodicals, 7 pamphlets, 306 dissertations in printed form, 149 dissertations on microfilm and 1 volume on microfilm. He reported that during the year considerable progress had been made on the project of securing copies of all American doctoral dissertations for the library. From the gift to the library by Professor R. C. Archibald, former Librarian of the Society, a microfilm reader has been purchased which is installed in the reading room and is available for use by members of the Society.

The Bulletin Editorial Committee reported that it would publish approximately 1,000 pages in the 1943 volume and that, because the present supply of unpublished manuscripts is very small, prompt publication is now possible. The editors also pointed out that, while shorter papers are desired, there is no longer an adherence to any strict rule of length.

The Transactions Editorial Committee reported that it expected to publish about 1,065 pages in 1943 and that, in spite of the fact that there is no present backlog of papers, at least Volume 55 would be of normal size. It was reported that Professor A. A. Albert would be Managing Editor during 1944-1945 and that Professors G. A. Hedlund, Nathan Jacobson, W. T. Reid, N. E. Steenrod, and Antoni Zygmund had been appointed Associate Editors, to replace Professors T. H. Hildebrandt, R. E. Langer, H. P. Robertson, and Gabor Szegö. The retirement of Professor Einar Hille from the Editorial Committee of the Transactions marks the end of an unusual record of twenty-one years of continuous connection with the editorial work of this journal. The Society has been fortunate to have had his wise counsel and devoted service for this long period.

The Mathematical Reviews Editorial Committee reported that there had been a marked decrease in the amount of mathematical material published throughout the world, that the editors had been able to obtain material from Russia regularly, and that an almost 
complete supply of material published in Germany up to the beginning of 1943 had been secured.

The Council voted to place Mathematical Surveys on the same basis as the Colloquium Series in the regulations concerning special privileges for enlisted men. The regulations as amended at the Summer and Annual Meetings were distributed to all members of the Society on January 1.

President Stone reported to the Council that the War Policy Committee is actively studying problems concerning the proper use of mathematicians in the war. Department chairman are urgently requested to inform the Secretary concerning cases in which the new deferment procedures lead to the improper classification of a mathematician. (The new procedures were described in a memorandum published in the November issue of this Bulletin.) It was further reported that an active subcommittee of the War Policy Committee (Professor W. L. Hart, Chairman) is studying the mathematical aspects of the various war training programs. A report was presented by the Committee on Available Teachers of Collegiate Mathematics. The Committee reported that the present supply of available teachers would not be adequate to meet the anticipated demands and urged all members of the Society to inform the Committee of persons who are available for appointment as teachers in the war training programs.

Titles and cross references to papers read at the meeting follow below. Papers 1 to 9 were read Friday morning, papers 10 to 18 Friday afternoon, papers 19 to 26 Saturday morning, papers 27 to 36 Saturday afternoon, and papers 37 to 56 , whose abstract numbers are followed by the letter $t$, were read by title. Paper 6 was read by Professor Ulam, 11 by Dr. Caton, 16 by Dr. Wetzel, 25 by Professor Eilenberg, 26 by Dr. Erdös, and 27 by Mr. Fine. Mr. Kenneth Levenberg was introduced by Professor H. B. Curry, Dr. Angeline J. Brandt by Professor R. M. Thrall, and Mr. H. E. Salzer by Professor A. N. Lowan.

1. John DeCicco: Dynamical and curvature trajectories in space. (Abstract 49-11-297.)

2. Janet MacDonald: Conjugate nets in asymptotic parameters. (Abstract 50-1-46.)

3. Alice T. Schafer: Two singularities of space curves. (Abstract 4911-300.)

4. Isaac Opatowski: Isoperimetric problems in bending of cantilevers. (Abstract 50-1-40.) 
5. Kenneth Levenberg: $A$ method for the solution of certain nonlinear problems in least squares. (Abstract 49-11-286.)

6. L. W. Cohen and S. M. Ulam: On the algebra of systems of vectors and some problems in kinematics. (Abstract 50-1-38.)

7. G. Y. Rainich: Noncommutative relations. (Abstract 50-1-15.)

8. P. R. Halmos: In general a measure preserving transformation is mixing. (Abstract 50-1-44.)

9. J. L. Brenner: The linear homogeneous group. II. (Abstract 50-13.)

10. K. L. Nielsen: On operators for linear partial differential equations. (Abstract 50-1-30.)

11. W. B. Caton and Einar Hille: On the class of functions $H_{p}(1 / 2)$. (Abstract 50-1-23.)

12. S. E. Warschawski: On Theodorsen's method of conformal mapping of nearly circular regions. (Abstract 50-1-37.)

13. A. T. Lonseth: The propagation of error in linear problems. (Abstract 50-1-28.)

14. W. T. Reid: Expansion theorems for boundary problems of the calculus of variations. (Abstract 50-1-31.)

15. Anne L. Lewis: Sufficiency proofs for the problem of Bolza in the calculus of variations. (Abstract 50-1-27.)

16. H. S. Wall and Marion Wetzel: Positive definite forms and convergence theorems for continued fractions. (Abstract 49-9-216.)

17. W. J. Trjitzinsky: Problems of representation and uniqueness for functions of a complex variable. (Abstract 50-1-35.)

18. A. H. Copeland: The nature of turbulence. (Abstract 50-1-39.)

19. Dorothy M. Stone: An algebraic characterization of measure algebras. Preliminary report. (Abstract 49-11-249.)

20. J. V. Wehausen: A remark concerning a set of completely continuous transformations. (Abstract 49-11-274.)

21. J. W. T. Youngs: On surfaces of class $K_{1}$. Preliminary report. (Abstract 49-11-309.)

22. G. E. Schweigert: Periodic analysis for onto-homeomorphisms of semi-locally-connected continua. Preliminary report. (Abstract 50-151.)

23. M. E. Shanks: Monotone decompositions of continua. (Abstract 50-1-50.)

24. R. H. Fox: The complete homotopy group. (Abstract 49-11-306.)

25. Samuel Eilenberg and Saunders MacLane: Cohomology theory in groups. (Abstract 50-1-9.)

26. Paul Erdös and S. M. Ulam: Some combinatorial problems in set theory. Preliminary report. (Abstract 50-1-25.) 
27. N. J. Fine and Ivan Niven: The probability that a determinant be congruent to $a(\bmod m)$. (Abstract 50-1-11.)

28. M. M. Day: Arithmetic of ordered systems. (Abstract 50-1-6.)

29. R. M. Thrall: On the decomposition of modular tensors. II. (Abstract 49-11-250.)

30. Ralph Hull: A theorem on the unit groups of simple algebras. (Abstract 50-1-14.)

31. A. A. Albert: Quasiquaternion algebras. (Abstract 50-1-2.)

32. L. R. Wilcox: Modularity in Birkhoff lattices. (Abstract 50-117.)

33. R. H. Bruck: Some results in the theory of quasigroups. (Abstract 49-11-244.)

34. Angeline J. Brandt: The free Lie ring and Lie representations of the full linear group. (Abstract 49-11-243.)

35. Wade Ellis: Relations satisfied by linear operators on a vector space. (Abstract 50-1-10.)

36. V. G. Grove: The transformation of Čech. (Abstract 50-1-45.)

37. Bernard Friedman: A method of approximating the complex roots of polynomial equations. (Abstract 49-11-280-t.)

38. D. G. Bourgin and C. W. Mendel: Orthonormal sequences. (Abstract 50-1-21-t.)

39. S. M. Ulam: Theory of the operation of product of sets. III. Preliminary report. (Abstract 50-1-36-t.)

40. Edward Kasner and John DeCicco: Union-preserving transformations of space. (Abstract 49-11-298-t.)

41. M. H. Heins: On the problem of Milloux for functions analytic throughout the interior of the unit circle. (Abstract 49-11-262-t.)

42. R. E. Johnson: On the equation $\chi \alpha=\gamma \chi+\beta$ over an algebraic division ring. (Abstract 49-11-246-t.)

43. M. E. Shanks: The space of metrics on a compact metrizable space. II. (Abstract 49-11-308-t.)

44. H. B. Curry: The method of steepest descent for nonlinear minimization problems. (Abstract 49-11-278-t.)

45. Dorothy M. Stone: The representation of abstract measure functions. (Abstract 49-11-273-t.)

46. R. H. Bruck: Some results in the theory of linear non-associative algebras. (Abstract 50-1-4-t.)

47. Morris Marden: A recurrence formula for the solutions of certain partial differential equations. (Abstract 50-1-29-t.)

48. Claude Chevalley: Some properties of ideals in rings of power series. (Abstract 50-1-5-t.) 
49. H. E. Salzer: New tables and facts involving sums of four tetrahedral numbers. (Abstract 50-1-16-t.)

50. A. A. Albert: Quasigroups. II. (Abstract 50-1-1-t.)

51. L. R. Wilcox: Theory of traffic light networks. I. (Abstract 50-142-t.)

52. A. R. Schweitzer: On functional equations with solutions containing arbitrary functions. III. (Abstract 50-1-32-t.)

53. G. T. Whyburn: Mapping classes for locally connected continua. (Abstract 50-1-52-t.)

54. B. H. Colvin: The expansion problem associated with a third order ordinary differential system of highly irregular type. (Abstract 50-1-24-t.)

55. Alfred Brauer: On certain limits. (Abstract 50-1-22-t.)

56. R. L. Moore: Concerning webs in the plane. (Abstract 50-149-t.)

W. L. Ayres, Associate Secretary 


\section{APPENDIX}

\section{EXCERPTS FROM REPORT OF TREASURER}

To THE BoARd of Trustees of the

December 10, 1943 American Mathematical Society

Gentlemen:

I have the honor to submit herewith the report of the Treasurer for the fiscal year ended November 30,1943 . The following remarks may be of interest.

\section{Investment Portfolio}

On November 30, 1943 the market value of the securities held for Invested Funds was $\$ 6,208$ less than book value. This is to be compared with the total amount, $\$ 17,416$, held in accounts "Reserve for Investment Losses" and "Profit on Sales of Securities." This total amount of reserves has now reached nearly ten per cent of the total value of Invested Funds. In view of the conservative character of many of the securities, these reserves may be considered sufficient protection against contingent depreciation in market value. The considerable increase, $\$ 8,843$, in this profit account during the year reflects two policies embodied in the recommendations of the Custodian and followed by the Board of Trustees-sales of railroad bonds which had been held on the books at depreciated values, and sales of certain common stocks when rising market values increased the percentage of common stocks in the portfolio beyond the point deemed desirable.

The market value of securities held for Current Funds was $\$ 654$ less than the book value. Profit on sales of securities for Current Funds amounting to $\$ 612$ is being carried as a reserve against losses to these funds.

The investment portfolio now includes government bonds $29 \%$, other bonds $24 \%$, preferred stocks $11 \%$, common stocks $28 \%$, cash in savings banks $8 \%$.

\section{Income from Investments}

Income received during the year from investment of Current Funds amounted to $\$ 1,254$, exclusive of income earmarked for International Congress, $\$ 96$, and Reilly Fund, $\$ 22$. This represents a return of slightly under $2 \frac{3}{4} \%$, computed on average book value of investments. 
Income on Invested Funds amounted to $\$ 6,352$, representing a return of $3 \frac{3}{4} \%$ computed similarly. Total investment income from all sources was thus $\$ 7,724$, representing a return of nearly $3 \frac{1}{2} \%$. In comparing this income and yield with $\$ 8,794$ and approximately $4 \%$ for the fiscal year 1942, there is reflected to some extent the changes in the character of the securities resulting from the sales mentioned above and the purchase of substantial amounts of government bonds. Also the figures for 1942 were somewhat too high to be truly representative, because of the receipt of a considerable sum of accrued back interest on certain railroad bonds then held. In view of the decreased rate of return, it is particularly fortunate that the Henderson Estate provided additional income of $\$ 4,438$.

\section{Increase in Surplus}

The increase in Surplus of $\$ 9,553$, as compared with $\$ 5,153$ in the preceding fiscal year requires some explanation. If it be noted that 1942 income from the Henderson Estate amounting to $\$ 2,275$ had not been added to Surplus on November 30,1942, but was so added during the current fiscal year, more proper figures for comparison are seen to be $\$ 7,278$ for 1943 and $\$ 7,428$ for 1942 . That the net result of the year's operations proved about as favorable as that for the preceding year is particularly satisfactory in view of the founding of Mathematical Surveys, made possible partly by the use of income from special funds (in the case of the Reilly Fund to such an extent that there is a small deficit in income account!), of somewhat increased expenses for other purposes, of the support of the War Policy Committee, and of the decrease in income from the Society's investments. However, a grant of $\$ 2,500$ from the Rockefeller Foundation, half of which has been received, prevented the support of the War Policy Committee from seriously depleting Surplus. And an increase in membership that resulted in an increase in dues, together with a slight increase in subscriptions to the Bulletin and to the Transactions, were other favorable factors that enabled the Society to come successfully through a year which at its beginning threatened to be rather difficult financially.

Respectfully submitted,

Bennington P. Gill, Treasurer 
BALANCE SHEET

Assets

Current funds:

November November

$30,1943 \quad 30,1942$

Cash

$\$ 19,846.11$

Investments.

INVESTED FUNDS:

$\$ 1,273.67$

$\$ 1,409.62$

Cash.........
Investments.

Total Assets

\section{Liabilities}

CURRENT Funds:

Mathematical Reviews

$\$ 14,252.62$

Colloquium

$5,761.69$

Mathematical Surveys.

840.03

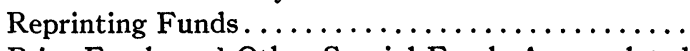

Prize Funds and Other Special Funds Accumulated Income...........................

Reilly Fund Principal.....................

International Congress....................

Miscellaneous..........................

Income from Henderson Estate. .............

Sinking Fund..$\ldots \ldots \ldots \ldots \ldots \ldots \ldots \ldots$

Profit on Sales of Securities...................

Surplus.

$2,239.10$

$2,296.18$

$6,146.06$

80.99

$\$ 16,184.69$

$2,805.04$

$1,329.15$

$4,848.52$

$3,968.13$

$6,050.33$

592.34

173.99

$2,275.00$

612.86

515.99

$23,755.30$

295.73

$14,201.68$

$\$ 56,577.17$

INVESTED FUNDS:

$52,648.25$

Endowment Fund Principal...............\$60,110.68

Prize Funds and Other Special Funds......... 31,033.22

Life Membership and Subscription Reserve...... 4,434.81

Colloquium........................... $5,000.00$

Mathematical Reviews.................. 60,000.00

Reserve for Investment Losses............... 4, 4,385.89

Profit on Sales of Securities.............. 13,030.36

$\$ 60,110.68$

$26,935.07$

$4,835.09$

$5,000.00$

$60,000.00$

$3,537.46$

$4,187.00$

$\$ 177,994.96$

$\$ 164,605.30$

Total Liabilities 


\section{SUMMARY STATEMENT OF INCOME AND EXPENDITURES}

1942-1943

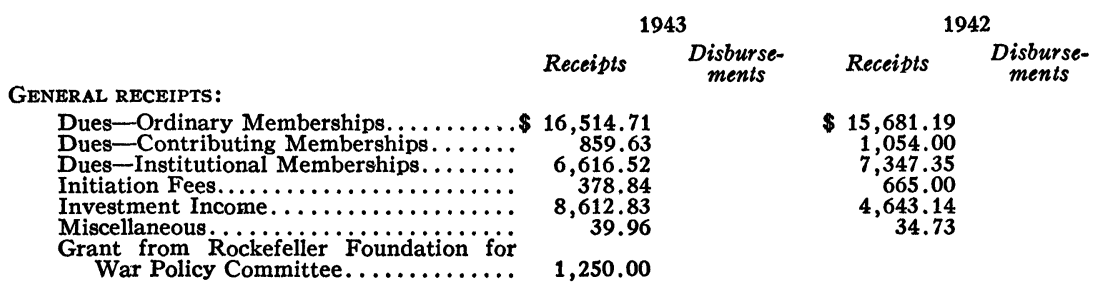

GeNERAL DISBURSEMENTS:

Secretaries. .....................

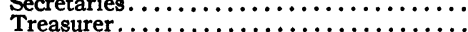

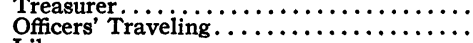

Library...$\ldots \ldots \ldots \ldots \ldots \ldots \ldots \ldots \ldots \ldots \ldots$

Committee Expenses....................

Emergency..............................

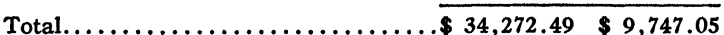

Excess of General Receipts.........\$24,525.44

$5,590.02$

$1,093.58$

581.23

893.15

$\mathbf{1 , 5 8 4 . 1 7}$

4.90

Publication:

Bulletin. $\ldots \ldots \ldots \ldots \ldots \ldots \ldots \ldots \ldots \ldots \ldots \$ 1,710.80 \quad \$ 11,536.88$

Bulletin Reprinting................... ${ }_{\mathbf{6 2 6}}^{7} .71$

Transactions

Transactions Reprinting................ $\mathbf{1 , 1 7 2 . 4 0}$

Colloquium ........................ $\quad \mathbf{3}, 951.38$

Mathematical Reviews................ $10,235.88$

Mathematical Surveys.............. $10,600.89$

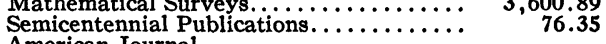

$8,309.42$

994.73

$12,167.95$

$2,760.86$

$2,500.00$

Total....................... \$27,261.24 \$39,159.00

Excess of Cost of Publication......... $\$ 11,897.76$

Miscellaneous:

Special Funds (including Congress) $\ldots \ldots \ldots \$ 1,273.41 \$ 3,600.00$

Profit on Sales of Securities..............

Income from Henderson Estate............

Income from Henderson Estate $\ldots \ldots \ldots \ldots$

Gift from R. C. Archibald $\ldots \ldots \ldots \ldots \ldots \ldots \ldots$

From Surplus:

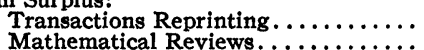

Mathematical Surveys.............

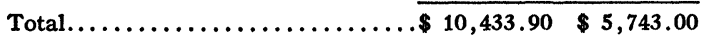

Difference.

, 160.49

80.97

12.03

750.00

300.00 $1,000.00$

Net Change in Assets.

$4,690.90$

$\$ 17,318.58$

$\$ 217,253.55$

$\$ 234,572.13$

ASSETS END OF YEAR.
$\$ 5,136.86$

794.36

643.61

569.95

67.92
5.71

$\$ 29,425.41 \$ 7,218.41$

$\$ 22,207.00$

\$ $1,673.13 \$ 12,101.37$

467.30
4

$5,787.17 \quad 9,373.59$

$\begin{array}{rr}274.58 & 9,373.59 \\ & 201.59\end{array}$

$3,814.97 \quad 6,197.07$

$10,809.17 \quad 11,548.93$

95.90

$2,500.00$

$\$ 22,922.22 \$ 41,922.55$

$\$ 19,000.33$

$\$ 1,442.39$

$2,713.28$

$2,275.00$

100.00

$\begin{array}{ll}73.99 & 103.86\end{array}$

100.00

$\$ 6,604.66 \$ 2,303.86$

$\$ 4,300.80$

$\$ 7,507.47$

$\$ 209,746.08$

$\$ 217,253.55$ 